\title{
Performance of industrial buildings during the Emilia earthquakes in Northern Italy and recommendations for their strengthening
}

\author{
Dionysios A. Bournas • Paolo Negro • Fabio F. Taucer
}

Received: 22 August 2012 / Accepted: 21 May 2013 / Published online: 7 June 2013

(C) The Author(s) 2013. This article is published with open access at Springerlink.com

\begin{abstract}
A series of earthquakes, the highest of magnitude $\mathrm{M}_{\mathrm{w}} 5.9$, hit a portion of the Po Valley in Northern Italy, which was only recently classified as seismic. The paper reports the findings and the lessons learnt from a preliminary field survey which was conducted immediately after the second event. As a result of the economic attitude of the affected area, and possibly of the characteristics of the event, an unprecedented number of industrial precast buildings were affected, resulting into most of the casualties as well as in large economic losses. Whereas most of the damaged and collapsed buildings were designed for gravity loads only, evidence of poor behavior of some precast buildings designed according to seismic provisions were discovered. The paper provides a description of the performance of precast buildings, highlighting the deficiencies that led to their poor behavior as well as some preliminary recommendations.
\end{abstract}

Keywords Industrial buildings · Precast structures - Connections · Cladding elements · Simply supported beams $\cdot$ Steel storage racks

\section{Introduction and background}

There are many evidences about the behaviour of precast structures during past earthquakes. This is for instance the case of earthquakes such as the 1976 Friuli (Italy) Earthquake (EERI 1979), the 1977 Vrancea Earthquake (Tzenov et al. 1978), the 1979 Montenegro Earthquake

D. A. Bournas $(\varangle)$

Department of Civil Engineering, University of Nottingham, NG7 2RD Nottingham, UK

e-mail: dionysios.bournas@nottingham.ac.uk

P. Negro · F. F. Taucer

European Laboratory for Structural Assessment, Joint Research Centre,

Institute for the Protection and Security of the Citizen,

European Commission, T.P. 480, 21020 Ispra, VA, Italy

e-mail: paolo.negro@jrc.ec.europa.eu

F. F. Taucer

e-mail: fabio.taucer@jrc.ec.europa.eu 
(Fajfar et al. 1981), and the 1988 Spitak Earthquake (EERI 1989). More recently, experience has been gained in more modern structures after the Northridge Earthquake (Bonacina et al. 1994) and the Kocaeli Earthquake (Saatcioglu et al. 2001; EERI 2000).

The main causes associated to the damage of the precast structures in these earthquakes were failure of connections, insufficient ductility of the columns, insufficient stiffness of the roof or slab system, being failure of the connections the main factor leading to most of the collapses. However, existing knowledge is rather incomplete and controversial. In fact, in most past earthquake events there is evidence of excellent behaviour of precast structures as well as reports of catastrophic collapses, which does not come as a surprise, since performance depends upon the specific structural system, the type of connections, the adequacy of the design and the quality of construction.

Restricting the focus to precast frames, the typology which is most commonly used in Europe, evidences of very good structural behaviour go hand in hand with reports of collapses, as in the already mentioned cases of Friuli and Kocaeli Earthquakes. For this kind of structures, recent evidence after the 2009 L'Aquila Earthquake (Monitoring and Information Centre (MIC) 2009) seems to demonstrate that the behaviour of such structures is satisfactory, whereas some problems exist with the non-structural components connections, in particular with the heavy cladding elements as was reported by Toniolo and Colombo (2012).

The present paper follows a technical mission to the area affected by the Emilia earthquakes. The economic activities of the area, in which a large number of small-size industrial facilities were concentrated, and possibly the specific characteristics of the earthquakes, resulted into an unprecedented number of precast buildings being affected by the earthquakes, with a large percentage of them being damaged or destroyed. The lessons which can be learnt from this experience are of much importance because of the coexistence of modern seismically designed buildings and of, still recent, non-seismically designed ones. The consequences are profound both for the risk which is represented by some non-seismically designed precast structures and for the importance of carefully designing the connections in modern buildings.

\section{Description of the event}

On 20 May 2012, at $02 \mathrm{~h} 09 \mathrm{~min}$ (UTC)—04h $09 \mathrm{~min}$ (local time), a $5.9 \mathrm{M}_{\mathrm{w}}$ magnitude (as estimated by the National Institute of Vulcanology and Geophysics of Italy, INGV) earthquake occurred at Finale Emilia, Province of Modena in Northern Italy, at a depth of $6.3 \mathrm{~km}$. The main shock was followed by two very strong aftershocks, the strongest of which $\left(\mathrm{M}_{\mathrm{L}}=5.8\right)$ occurred on May 29 at $07 \mathrm{~h} 00 \mathrm{~min}(\mathrm{UTC}) — 09 \mathrm{~h} 00 \mathrm{~min}$ (local time) at Medolla (Province of Modena). The authors conducted their survey in the affected region immediately after the first aftershock. A last strong aftershock of $5.1 \mathrm{M}_{\mathrm{W}}$ magnitude took place on June 3 at $19 \mathrm{~h} 20 \mathrm{~min}$ (UTC) - $17 \mathrm{~h} 20 \mathrm{~min}$ (local time) at Novi di Modena. The whole area affected by the earthquakes, including all epicentres, is approximately $60 \mathrm{~km}$ (East-West) $\times 30 \mathrm{~km}$ (NorthSouth). The areas mostly affected by the earthquakes comprise the municipalities of San Felice sul Panaro, Sant'Agostino, San Carlo, Finale Emilia, Mirandola, Medolla, Cavezzo, Concordia sulla Secchia and Novi di Modena, with a toll of 23 casualties, 400 injured and a total of approximately 20,000 homeless. The USGS PAGER System (http://earthquake. usgs.gov/earthquakes/pager/) estimated that the economic losses were in the range of $1 \%$ of the national GDP. According to results provided by the Italian Civil Protection, for a total of 6,700 structures inspected $37 \%$ were habitable, $17 \%$ temporary uninhabitable but habitable following emergency measures, $6 \%$ partially uninhabitable, $2 \%$ temporary uninhabitable 
Table 1 Maximum recorded PGA, PGV and PGD (INGV)

\begin{tabular}{llllllllr}
\hline Station & Date & Direction & $\begin{array}{l}\text { Magnitude } \\
\left(\mathrm{M}_{\mathrm{L}}\right)\end{array}$ & $\begin{array}{l}\text { Location- } \\
\text { Province }\end{array}$ & $\begin{array}{l}\text { Distance } \\
\text { from } \\
\text { epicenter } \\
(\mathrm{km})\end{array}$ & $\begin{array}{l}\text { PGA } \\
\left(\mathrm{cm} / \mathrm{s}^{2}\right)\end{array}$ & $\begin{array}{l}\text { PGV } \\
(\mathrm{cm} / \mathrm{s})\end{array}$ & $\begin{array}{r}\text { PGD } \\
(\mathrm{cm})\end{array}$ \\
\hline MRN & 20 May & Vertical (HGZ) & 5.9 & Mirandola & 17 & 303 & 5.9 & 2.3 \\
MRN & 20 May & E-W (HGE) & 5.9 & Mirandola & 17 & 256 & 30 & 9.2 \\
MRN & 20 May & N-S (HGN) & 5.9 & Mirandola & 17 & 260 & 47 & 14 \\
MRN & 29 May & Vertical (HGZ) & 5.8 & Mirandola & 2 & 900 & 28 & 11 \\
MRN & 29 May & E-W (HGE) & 5.8 & Mirandola & 2 & 220 & 29 & 9.2 \\
MRN & 29 May & N-S (HGN) & 5.8 & Mirandola & 2 & 290 & 57 & 18 \\
\hline
\end{tabular}

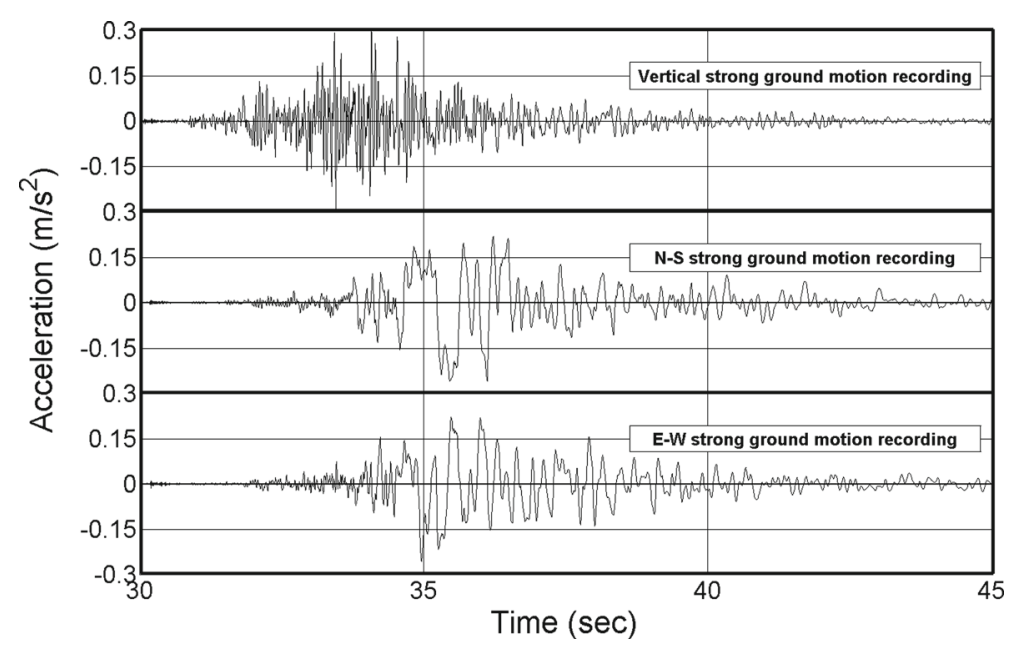

Fig. 1 Vertical, N-S and E-W strong ground motion recordings at Mirandola station, 20 May 2012, 04:09 (UTC) $\mathrm{M}_{\mathrm{L}}=$ 5.9. (Source: Italian Civil Protection)

and to be reviewed in more detail, $33 \%$ uninhabitable and $5 \%$ uninhabitable due to external factors (such as near-to-collapse neighbouring buildings).

A series of accelerometer stations of the RAIS (Strong Motion Network of Northern Italy) and RAN (National Strong Motion Network) networks were installed in the affected area, some already existing, and others installed following the first event. Table 1 presents a summary of the maximum recorded accelerations for each orthogonal component obtained from the stations that were closest to the epicentre. Figure 1 presents the time histories of the E-W, $\mathrm{N}-\mathrm{S}$ and vertical components of the acceleration recorded at the Mirandola (MRN) station. The maximum recorded peak ground acceleration (PGA) is in the order of $0.30 \mathrm{~g}$ (Fig. 1). The PGAs reported by the U.S. Geological Survey (USGS) and shown in Fig. 2 show that ground accelerations decayed concentrically very rapidly around the epicentre; accelerations in the order of $0.08 \mathrm{~g}$ are reported for the 29 May earthquake at $25 \mathrm{~km}$ from the epicentre. Differently from L'Aquila Earthquake, in which the mainshock was classified as a pulse-like event with strong directivity (Chioccarelli and Iervolino 2010), the velocity time histories did not show any full velocity cycles of structural engineering interest (Iervolino et al. 2012).

Figure 3 shows the response spectra of the N-S and E-W components of the ground motions recorded at the Mirandola station for both of the strong earthquakes of 20 and 29 


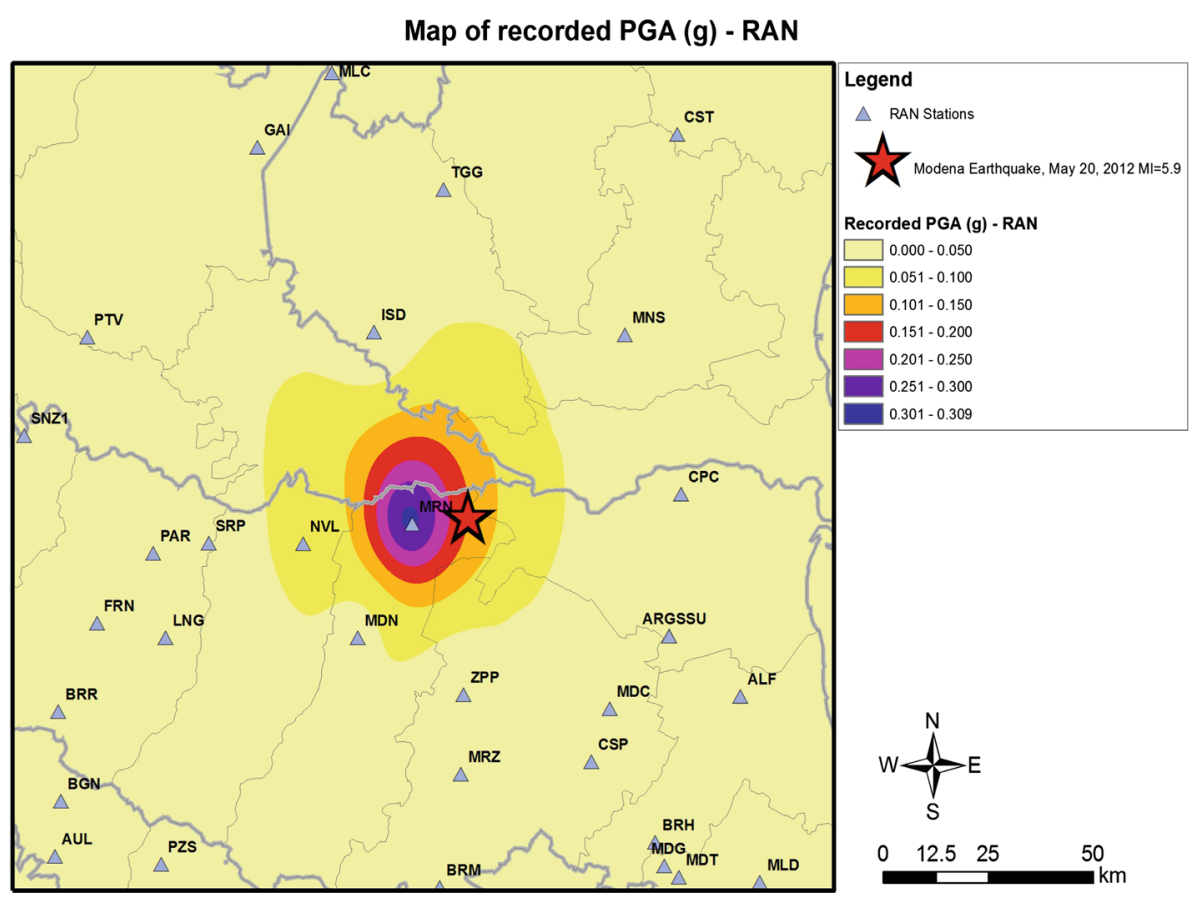

Fig. 2 Map of recorded PGA of some stations of the RAN network and the RAIS network in the area close to the epicentre after the 20 May event, 04:09 (UTC) $\mathrm{M}_{\mathrm{L}}=5.9$ (Source: USGS)

of May. As it can be observed, beyond the peak value of acceleration which occurred for low periods, only the $\mathrm{N}-\mathrm{S}$ component of the response spectra in both earthquakes shows high accelerations for higher periods. In particular, for periods in the range of $0.7-1.8 \mathrm{~s}$, the spectral acceleration of the $\mathrm{N}-\mathrm{S}$ component of the 29 May earthquake is approximately equal to half of its peak spectral value. This low frequency content of the $\mathrm{N}-\mathrm{S}$ component may have added to the high levels of damage experienced by structures with high periods of vibration, such as the relatively flexible precast industrial buildings. It should be noted here that the fundamental period of a typical single-storey industrial precast concrete building, calculated following a benchmark design study among Italy, Greece, Slovenia and Turkey, ranges between 0.8 and $1.4 \mathrm{~s}$ (Olgiati et al. 2011). Finally, it should be also pointed out that the second event was more damaging because of its higher energy content in low periods of vibration.

\section{Normative provisions for the affected area and typology of the precast industrial buildings}

A new seismic zoning of Italy was issued in 2003, which practically established a fourth seismic zone for all regions that before 2003 were considered as non-seismic. Figure 4 presents the Italian seismic zoning map for design before and after 2003, and shows that the area affected by the earthquakes was not classified as seismic before 2003. It should be considered that the seismic zoning issued in 2003 was waived during a grace period of 18 months, and in Italy the norms applied in construction are those in force at the time in which 


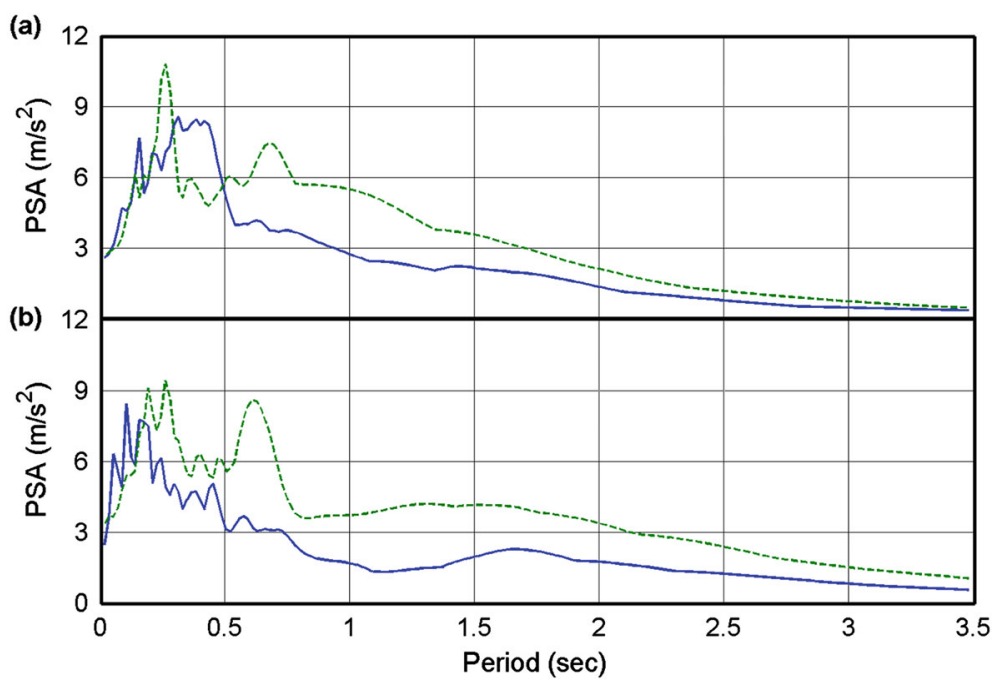

Fig. 3 Response spectra at Mirandola station in the N-S (green dashed line) and E-W (blue line) directions, for the earthquakes of: a 20 May 2012, 04:09 (UTC) $\mathrm{M}_{\mathrm{L}}=5.9$. b 29 May 2012, 07:00 (UTC) $\mathrm{M}_{\mathrm{L}}=5.8$ (Source: Italian Civil Protection)

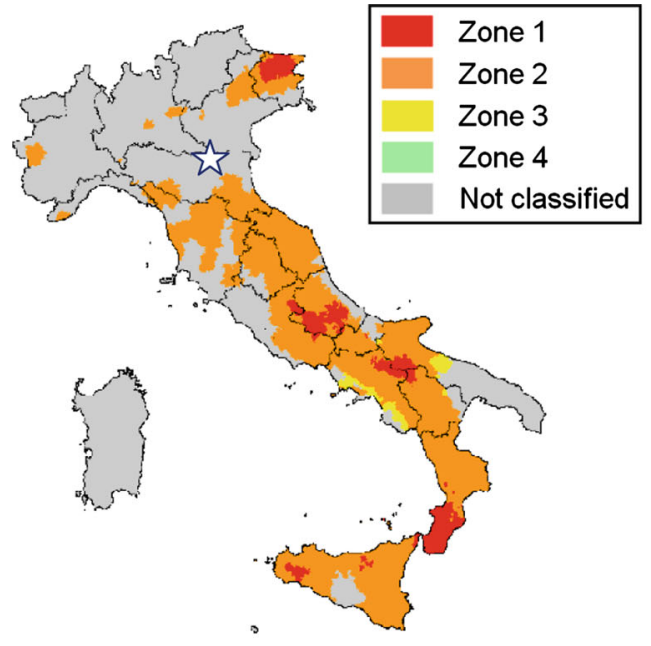

(a)

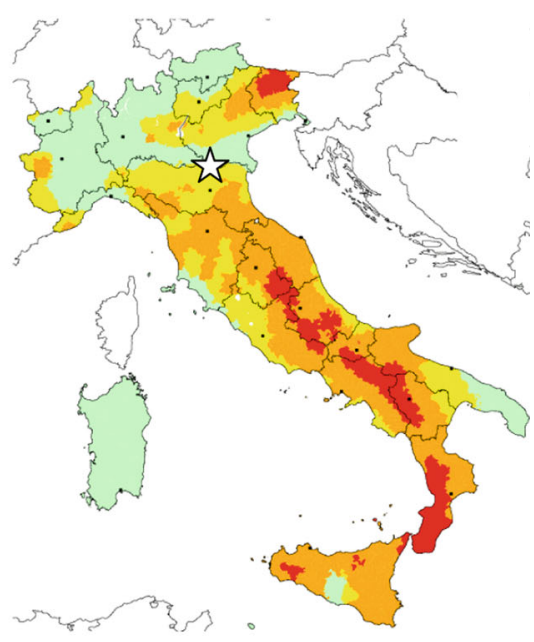

(b)

Fig. 4 Italian seismic zoning map for design: a Before 2003. b After 2003

the permission is filed at the local authorities and the permission might have been extended for years. As a result, it is very difficult to assess whether seismic provisions were taken into account with the sole estimation of the period of construction.

The current seismic design code of Italy, based on Eurocode 8 and approved in 2008 with its application waived for 18 months, divides the entire country into four regions, assigning peak ground accelerations of $0.05,0.15,0.25$ and $0.35 \mathrm{~g}$ for regions $4,3,2$ and 1 , respectively (Fig. 4b). The area most affected by the earthquakes is presently classified as Zone 3 (Fig. 4b), corresponding to $0.15 \mathrm{~g}$ PGA for a return period of 475 years. The maximum acceleration 
Fig. 5 Spectra of the N-S component of the two strongest records compared to the Italian code spectrum

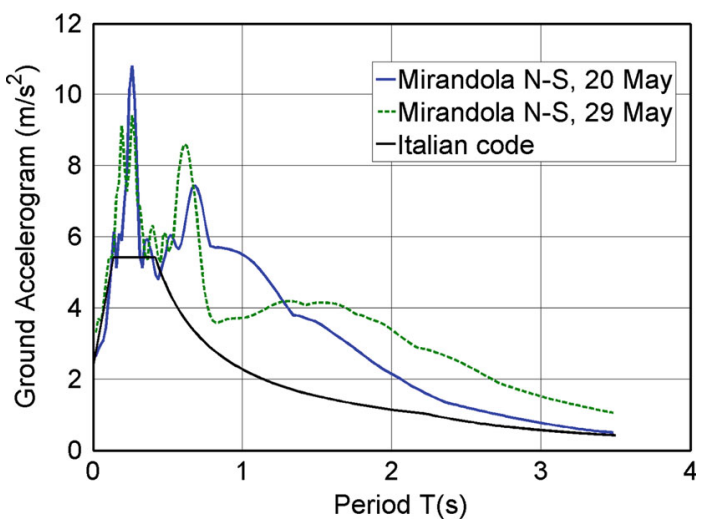

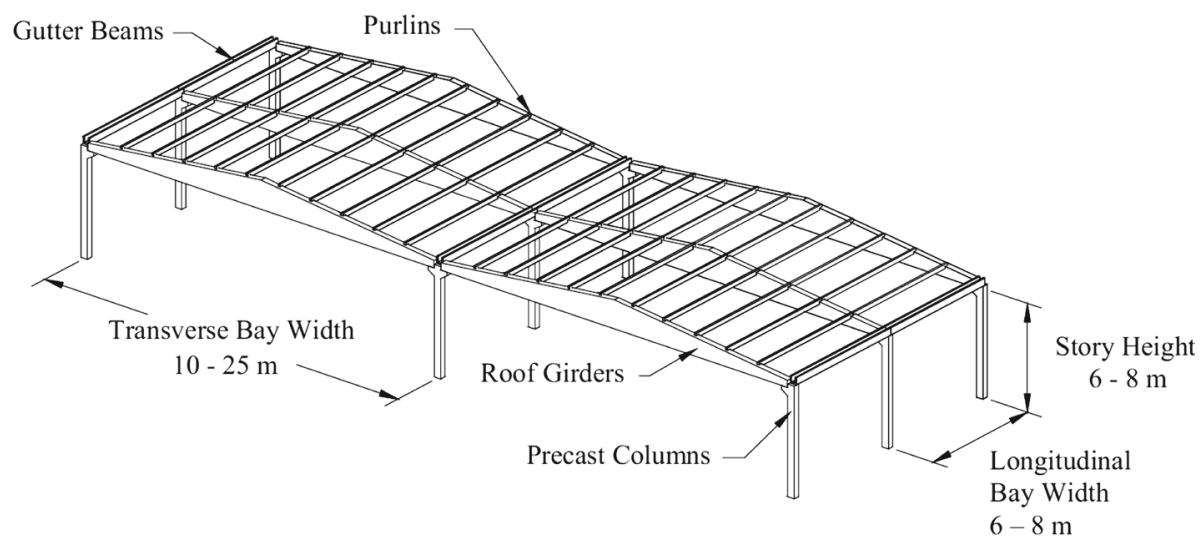

Fig. 6 Typical configuration of a one-storey precast concrete industrial building (Wood 2006)

recorded at Mirandola $(0.30 \mathrm{~g})$ corresponds to twice of the design acceleration given by the current codes $(0.15 \mathrm{~g})$. Figure 5 plots the spectra of the $\mathrm{N}-\mathrm{S}$ component of the two strongest records as compared with the current Italian code, both for ground type B and $5 \%$ viscous damping. It can be observed that the spectra from the recorded ground motions are consistently larger than the 475 years spectrum currently specified by the Italian norms.

These earthquakes revealed that the most vulnerable structures in the area were mainly the precast concrete industrial buildings, particularly those constructed without seismic provisions, and some historical unreinforced masonry buildings (i.e. churches, towers). Slight damage to motor-way bridge structures, to a new pilotis building and effects of liquefaction in the town of San Carlo were also observed. The focus of the paper on the performance of precast industrial buildings recognizes the important effect that the Pianura Padana-Emiliana earthquakes had on this type of structures, with no precedent in other earthquakes in Italy and Europe.

The most common typology used for the construction of single-storey industrial buildings in Italy is characterized by the use of precast reinforced concrete long-span roof girders supported over cantilever precast columns, which provides the large open spaces needed for manufacturing (Fig. 6-Wood 2006); the same typology is used in most seismic countries of the Southern Mediterranean region (e.g. Greece, Turkey, etc.). The buildings are rectangular in plan, with one or more bays in the transverse direction and several bays in the longitu- 
dinal direction. The width of the transverse bays ranges from 10 to $25 \mathrm{~m}$, the width of the longitudinal bays ranges from 6 to $8 \mathrm{~m}$, and storey height ranges from 6 to $8 \mathrm{~m}$. The base of each precast column is typically grouted into a precast pocket foundation to form a fixed connection. The long-span roof girders are oriented along the transverse axis of the building and, in the buildings without seismic provisions, are simply supported on column corbels (or forks). The depth of these girders often varies along the length, forming a triangular shape (double-slope girders). Beams are oriented along the longitudinal axis of the building, and quite often have a U-shaped cross-section, to function as gutters to collect water from the roof. Purlins span between the roof girders at regular intervals. The precast roof girders, gutter beams, and purlins are usually simply supported at both ends. Typically, lightweight materials are used to form the roof, which does not serve as a structural rigid diaphragm. Masonry or precast concrete wall panels are typically used for the exterior walls. The connection details for the wall panels are designed such that the panels do not contribute to the lateral stiffness of the building; however, this principle was not satisfied by the majority of the existing industrial precast concrete buildings in the affected area.

The connections between precast elements are the key element in determining the seismic performance of industrial precast buildings. The main issue relates to the capacity of beamto-column connections by either allowing for relative displacements without losing beam seating (i.e. for buildings designed for vertical forces only), or for adequately transferring lateral horizontal forces to the column and down to the foundation without losing capacity.

\section{Review of the damage}

\subsection{General observations}

Most of the precast industrial buildings in the affected area were designed for gravity loads only and were characterized by lack of beam-column joints capable of transferring the seismic forces down to the foundation, insufficient seating and isolated column foundations. A small number of buildings were designed and constructed during the last 5-7 years, presumably conforming to the updated seismic zoning of the area.

The findings of the field mission indicate that approximately three quarters of the precast concrete industrial buildings designed with non-seismic provisions in the affected area presented damage and detachment of the exterior cladding elements, with one quarter of the total presenting partial or total collapse of the roof, mainly due to the loss of seating of the main girder. Apart from one building that presented partial collapse, all precast industrial buildings designed with seismic provisions - based on the architecture of the buildings and discussions of the reconnaissance team with the owners and inhabitants of the affected area-presented no damage to the structural elements. The damage on non-structural elements, which typically comprised the detachment of cladding panels from the main structure due to insufficient capacity of the connections, were not significantly reduced in the buildings designed with seismic provisions.

\subsection{Structural damage}

\subsubsection{Buildings without seismic provisions}

The main vulnerability of the industrial buildings designed without seismic provisions concerns the inadequacy of the connections between precast elements. Other deficiencies 


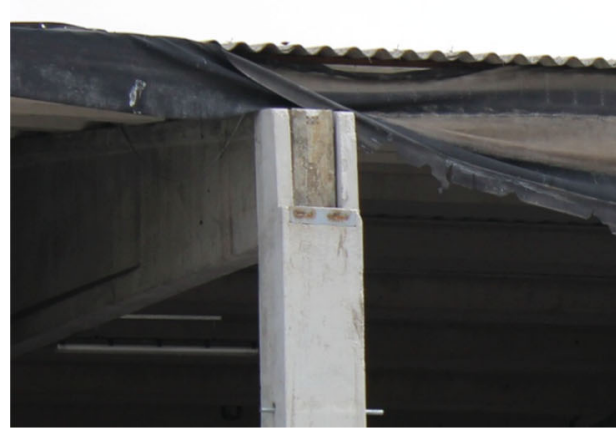

(a)

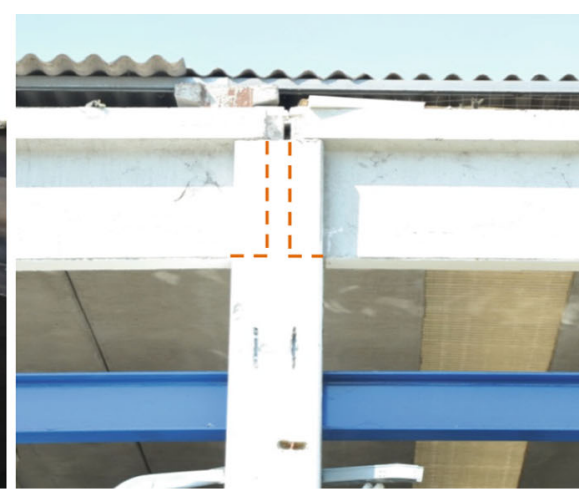

(b)

Fig. 7 a Seating of double slope precast beams showing the fork at the top of the column: seating at an end column. b Seating at an intermediate column of a "T" section beam (with dashed lines indicating the section of the beam at the seat pocket)

include insufficient transverse reinforcement in the columns, insufficient splice and anchorage lengths, lack of diaphragm effect at the roof level and isolated foundations. The floor/roof system and the beams, where most of the masses are concentrated, were not tied together and there were no means of transferring the inertial seismic loads to the lateral load resisting system, namely the columns.

The weak link in the vast majority of the industrial buildings visited was the absence of mechanical connections between roof-girders and columns. The most common typology corresponded to double-slope beams, simply supported over special openings (forks) at the top of columns as shown in Fig. 7. This typology was used in Italy during the 60s and 70s for agricultural buildings, now being replaced by the more common flat-roof systems. In this connection typology, the capacity of transferring lateral loads depends entirely on the static coefficient of friction between the supporting surfaces of beam and column and on the length of the beam seating when the friction forces are exceeded by the earthquake force demands.

The collapse of most of the precast buildings was due to unseating of the transverse girders from the columns' forks. The seating loss was in the majority of the cases observed in the central column, where the seating length of the girders was rather limited and the relative displacement between the column and girder exceeded the available width, as shown in Fig. 8. In some cases, the collapse of the girders took place in the out-of-plane direction of the girder, after failure at the base of the forks. Figure 9a illustrates the out-of-plane collapse of a double-slope precast beam after unseating, following failure of the lateral restraints of the fork at the seat pocket (the original location of the beam is shown in red dashed lines). Figure $9 \mathrm{~b}$ presents a detail of the failure of the lateral restraint, showing with red dashed lines the original undamaged geometry of the restrain at the fork.

The interaction with masonry panels distributed non-uniformly across the structure often led to non-synchronous displacements at the top of columns, thus contributing to unseating of the girders as presented in Fig. 10. Masonry panels, when not covering the full length of the column, led in many cases to the formation of short-column failures (Fig. 10).

Concerning the loss of seating of beams and columns, it is noted that the flat (Fig. 11) and the sloped roof systems are equally vulnerable. The main difference between the two systems is that the sloped roof corresponds to a generally older design, where the girder has a smaller width (due to its higher section height) that leads more easily to out-of-plane failures. 


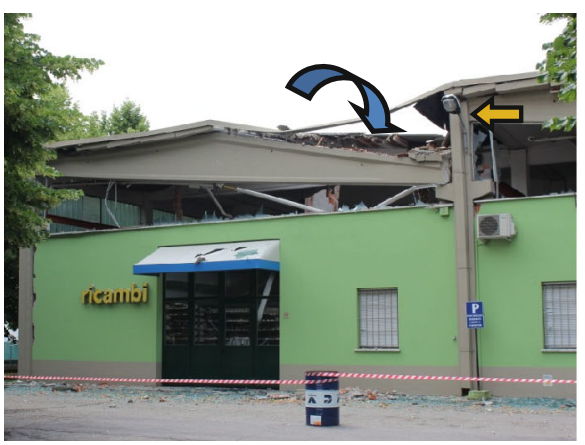

(a)

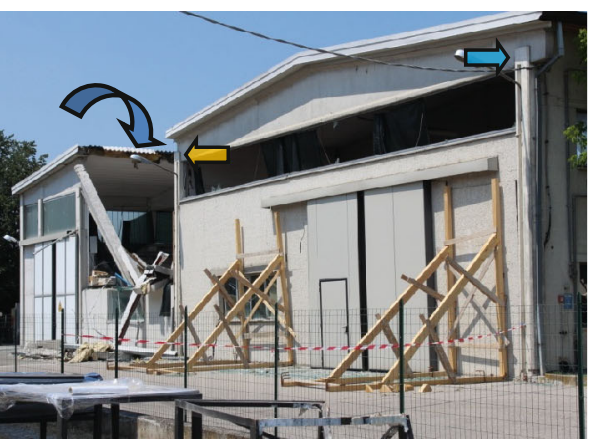

(b)

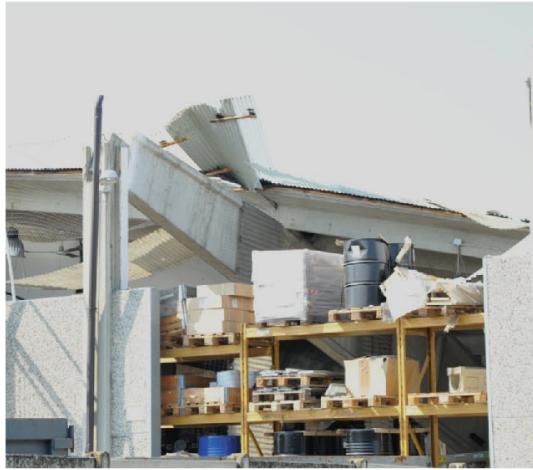

(c)

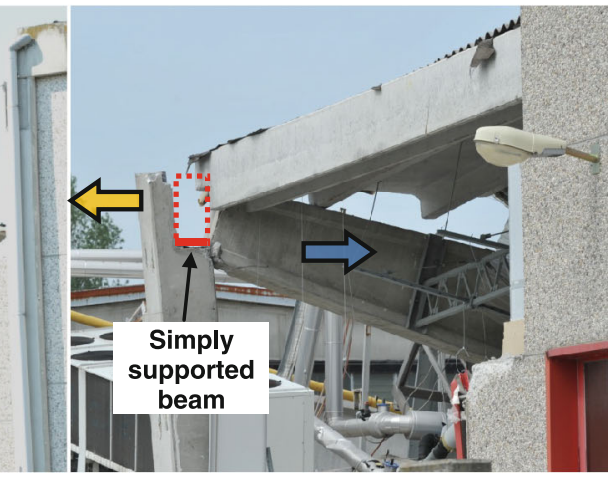

(d)

Fig. 8 a Loss of beam seating from the central column and associated collapse of a double slope precast beam (the blue curved arrow shows direction of collapse and the orange arrow shows the intermediate beam); b longer seating of the end beam at the external column (blue arrow); c, $\mathbf{d}$ Displacement of the beam from the external column's corbel following its collapse in the central column

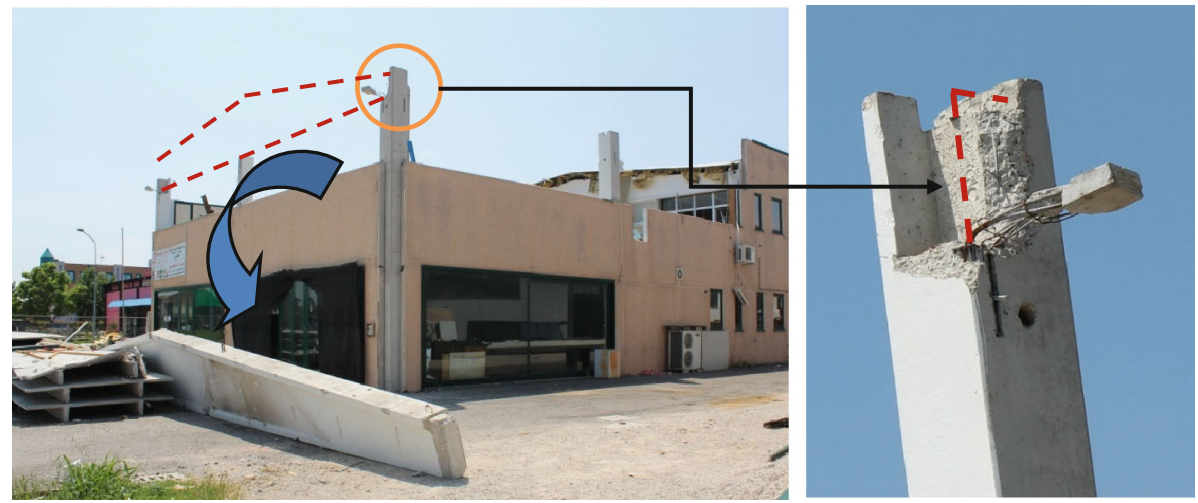

(a)

(b)

Fig. 9 a Out-of-plane collapse of a double slope precast beam after unseating following failure of the lateral restrain of the fork at the seat pocket; $\mathbf{b}$ detail of the shear failure of the fork 


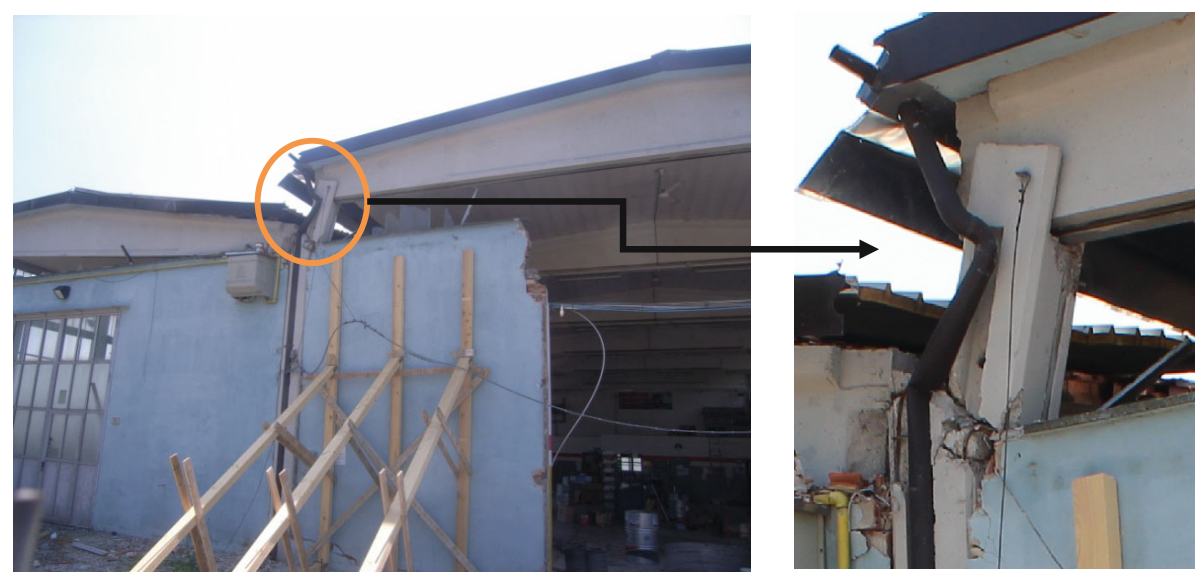

Fig. 10 Loss of the left girder seating due to the interaction with masonry panels (short columns/shear failure)

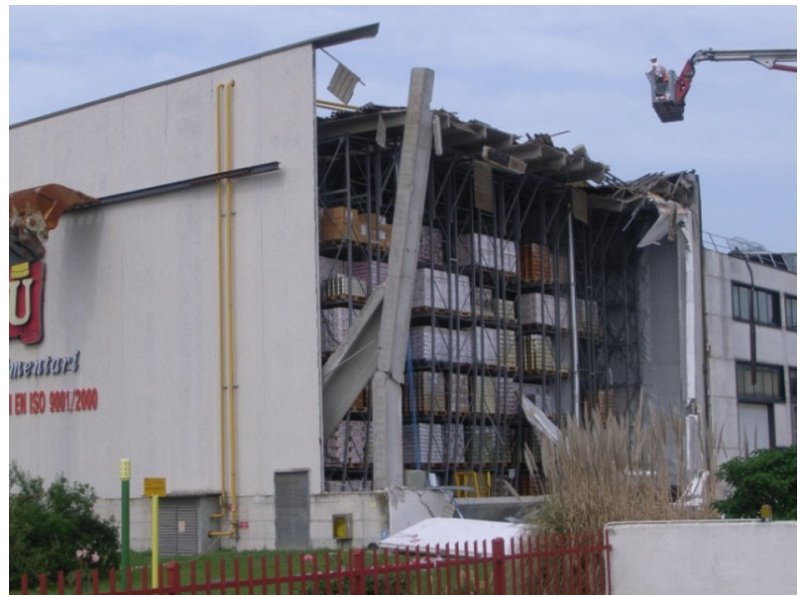

Fig. 11 Partial collapse of the roof, longitudinal girders, column and front cladding of a flat roofed precast building

Fig. 12 Detail of a pinned beam-column joint connection

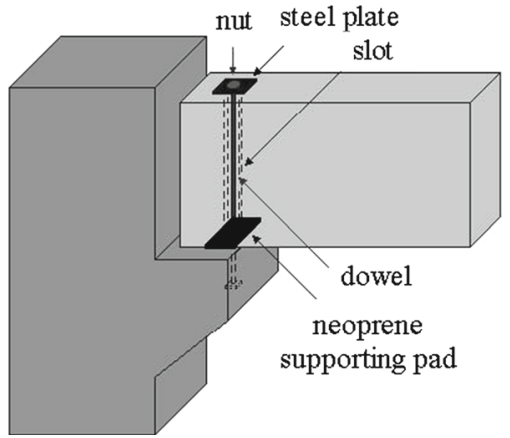



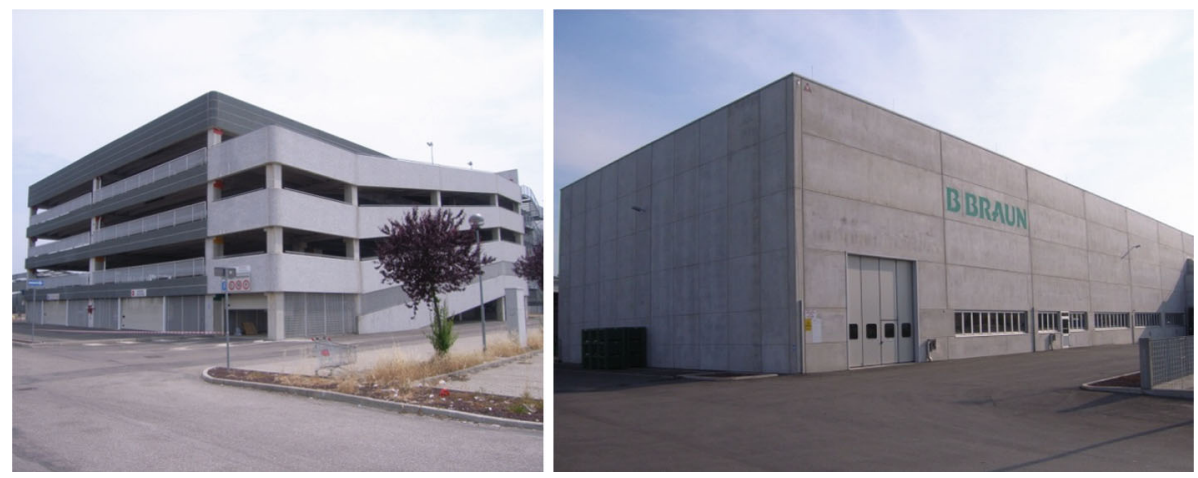

Fig. 13 Recently constructed precast concrete buildings exhibiting good performance

\subsubsection{Buildings with seismic provisions}

The main feature of precast industrial buildings constructed with seismic provisions lies in the type of beam-column connections. When horizontal forces are taken into consideration in design, the most common connection system for the construction of single-storey industrial buildings in Europe comprises hinged beam-column connections by means of dowel bars (shear connectors). This type of connection is able to transfer shear and axial forces resulting from the seismic actions. Practically, the horizontal beam-column connection is established by means of vertical steel dowels (typically one or two) which are protruding from the column into special beam sleeves, as shown in Fig. 12. This pinned beam-column connections are constructed by seating the beams on the column capitals and by holding the beam ends in place by the use of these vertical steel dowels.

In general, recently constructed precast concrete buildings, including a high-rise precast parking structure, which most probably incorporated steel dowels in the beam-column joints, exhibited apparent good performance, as shown in Fig. 13. It should be noted that, due to safety measures in force immediately after the main shocks, no inspection near or inside these buildings was possible.

It is worth mentioning that a building completed in 2010 showed partial collapse, in spite of having been designed (according to information provided by the owner) with pinned beam-column connections following the new Italian construction standards. Visual inspection revealed failure at the top of one of the central column beam-column connections. This failure was followed by loss of the girder seating and its subsequent collapse (Fig. 14a).

The rather limited distance of the dowels from the edge of the column and the limited amount of transverse reinforcement might have resulted into the formation of a shear crack across the concrete cover (Fig. 14b), followed by the loss of the dowels anchorage and consequently the loss of the girder seating. This failure reveals the absence of specific provisions for detailing the beam-to-column connections in the current Italian construction standards and the as well as in the Eurocodes (CEN 2004).

\subsection{Non-structural damage}

Most of the inspected buildings - designed with or without seismic provisions - presented failure of the connections of the cladding elements due to their insufficient displacement capacity that led to overturning of the cladding elements. The panel connections were 


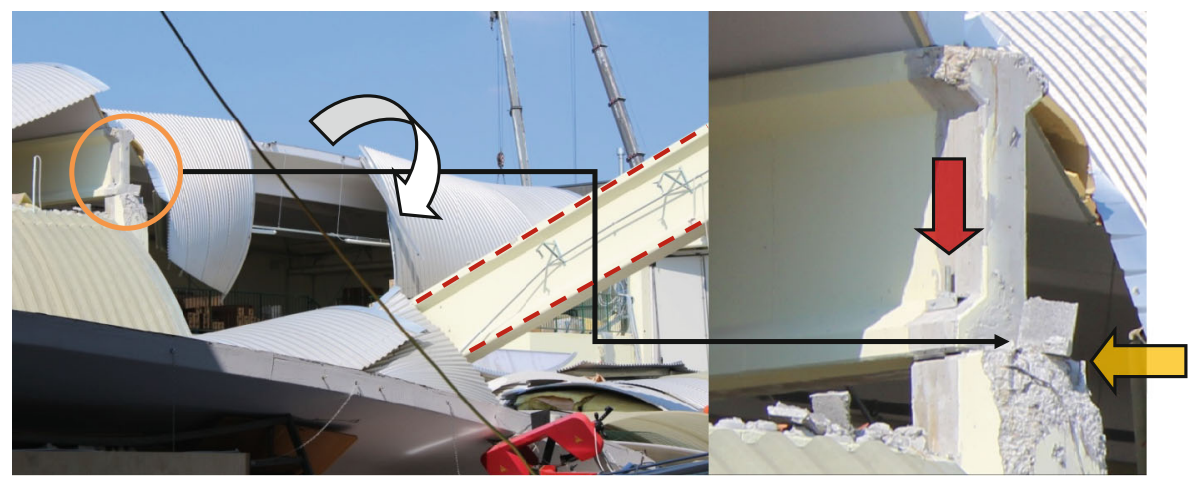

(a)

(b)

Fig. 14 Loss of girder seating in a recently constructed industrial building after failure of the pinned beamcolumn connection: a general overview of the collapsed beam (red dashed lines); $\mathbf{b}$ detail showing failure of the column support at the beam-column pinned connection. Orange arrow shows damaged area at the top of the column, while red arrow shows an undamaged pinned connection

designed to transfer the vertical (self weight) load of the panel, as well as any out-of-plane loading, to the main elements of the precast structure (beams and columns). For small drifts of the structure, the connections do not provide any in-plane stiffness interaction with the panels. However, during the earthquake the precast buildings might have been subjected to excessive interstorey drifts, as well as high out-of-plane inertial lateral forces, for which these connections were not designed for.

Current design practice for precast industrial buildings is based on a bare frame model, where the peripheral cladding panels enter only as masses, without any stiffness contribution. In addition, some designers introduce only the inertial mass contribution of the walls orthogonal to the plane of the walls. The panels are then connected to the structure with fastenings devices which are dimensioned by means of a local calculation, with anchorage forces orthogonal to the plane of the panels computed based on their mass and design spectral acceleration. The connecting devices are expected to allow for all other relative deformations. However, when the free relative deformation capacity of the connection is exceeded, the panels become an integral part of the resisting system, conditioning its seismic response. The high stiffness of this resisting system leads to much higher forces than those calculated from the frame model. These forces are related to the global mass of the floors and are primarily resisted in the plane of the walls. Furthermore, the seismic force reduction considered in precast structures relies on the energy dissipation resulting from the formation of plastic hinges at the columns bases. Due to the large flexibility of precast structures, very large drifts of the columns are typically needed to activate the energy dissipation mechanism assumed in design. However, the capacity of the connections between the cladding elements and the structure is typically exhausted well before such large drifts can develop.

Figure 15a illustrates the in-plane detachment of an exterior cladding element after failure of the connections (Fig. 15b) with the main structure. Similarly, the excessive drifts which were experienced by the precast building in Fig. 16 exhausted the displacement capacity of the connections of the panels, leading to the development of high forces that led to failure of the connections and unseating of the horizontal panel.

The design of the claddings connections proved to be insufficient also in the orthogonal direction. The out-of-plane inertial effects of the panel led to the development of high out-ofplane lateral forces that induced failure in the panel-to-frame and panel-to-panel connections. 


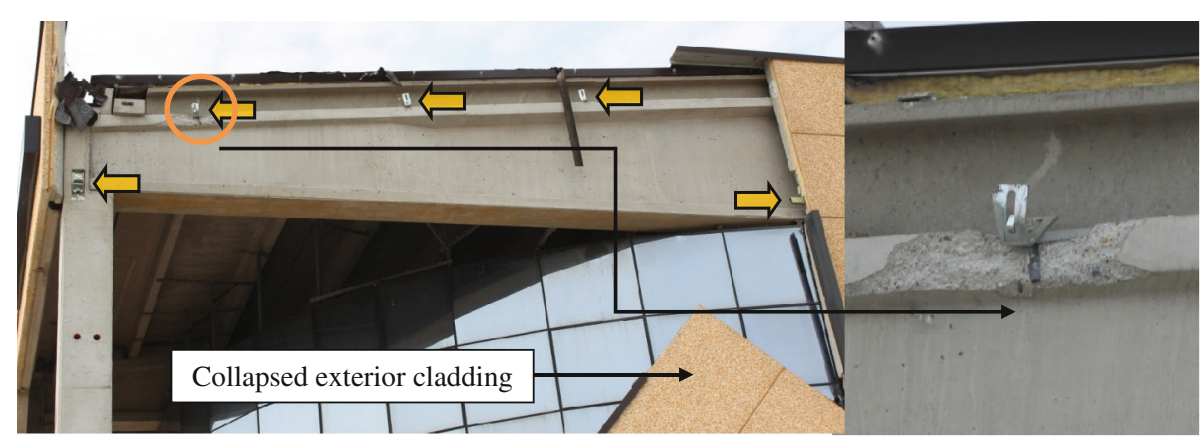

(a)

(b)

Fig. 15 a Cladding panel collapse after failure of the connections with the main structure (orange arrows showing the location of connections of the collapsed exterior cladding); $\mathbf{b}$ detail showing failure of the mechanical connection

Fig. 16 Detachment of exterior cladding after failure of the connections from the main structure: in plane rotation

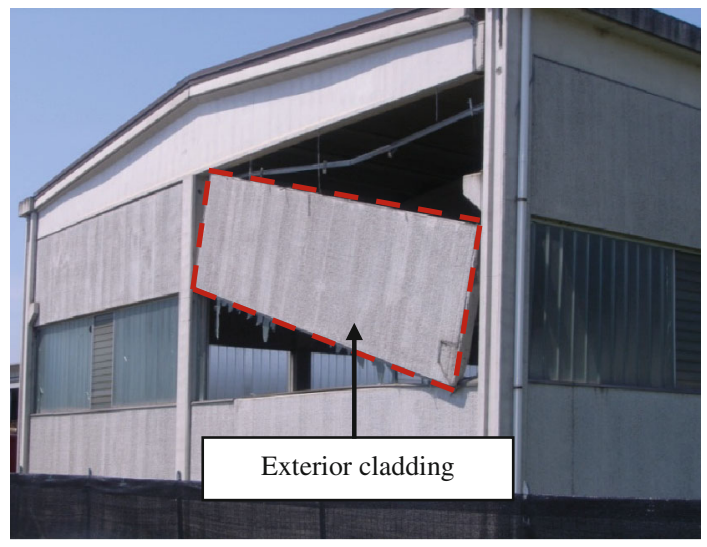

Figure 17a presents a horizontal panel detached from the frame, (possibly) due to the high outof-plane inertial seismic forces that caused failure of the fastenings (Fig. 17b). In other cases, the high out-of-plane inertial effects led to the development of high rotations (especially when more than two horizontal panels were used-Fig. 18), which together with vertical inertia effects, led to unseating and loss of the panel connection.

Finally, in some industrial buildings the failure of steel racking systems, especially very tall ones (in excess of $10 \mathrm{~m}$ ), was observed, with important economic consequences. In some cases, their large mass and the resulting high inertia forces developed during the earthquake induced ramming and consequent collapse of exterior cladding (Fig. 19).

\section{Strengthening measures}

\subsection{Summary of the damage observed and lessons learned}

The high damage and collapse of the precast industrial buildings — designed for gravity loads only-was due mainly to the absence of mechanical connections between beams and columns. Simply supported beam-column connections resulted into a large number of collapses induced 


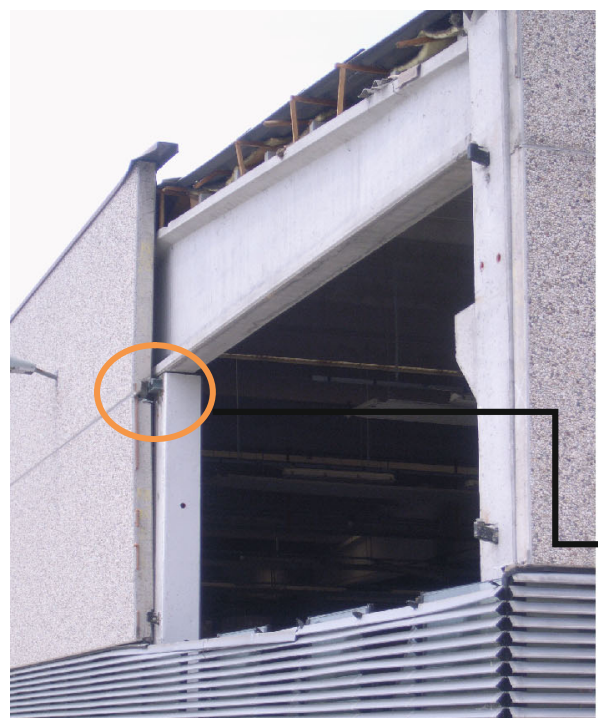

(a)

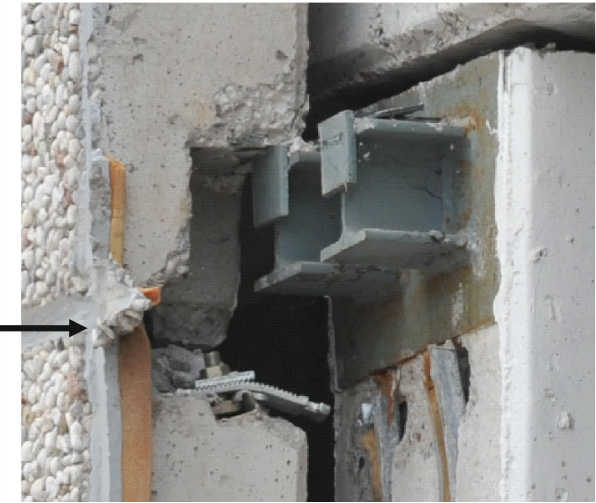

(b)

Fig. 17 Out-of-plane detachment of horizontal cladding: a overall view; $\mathbf{b}$ detail of the failed fastenings

by unseating of the transverse girders and longitudinal beams. The loss of seating mainly occurred in the central columns, where the seating length of the girders was shorter. In other cases the collapse of girders took place in the out of plane direction —of the girder-, after failure at the base of the forks. Recently constructed industrial buildings, which most probably incorporated steel dowels in the beam-column joints, exhibited a better seismic performance. However, the partial collapse of a building completed in 2010, in spite of having been designed with pinned beam-column connections following current Italian construction standards, brought in light the lack of specific provisions for the detailing of beam-to-column connections (including the Eurocodes).

The detachment of the cladding panels from the main structure due to the insufficient capacity of the connections was practically not improved in the newly constructed buildings. The panel connections were designed to transfer the vertical load of the panel, as well as any out-of-plane loading, to the precast structure, allowing for free deformations along the other directions. There were two types of loading situations for which the panel was not designed for: (i) excessive drifts that exhausted the fastenings sliding capacity and led to the development of high forces and fracture of the fastenings; and (ii) high out-of-plane inertial forces that led to the fastenings failure.

Finally, in some industrial buildings the failure of steel racking systems was observed: the high inertia forces developed during the earthquake induced ramming and consequent collapse of the exterior cladding.

After the second main shock it was decided by the local and national authorities that the tagging of precast industrial buildings for usability would have been made by civil engineers being called upon by building owners. For most of the precast buildings existing in the affected area (i.e., designed for gravity loads only) a tagging procedure solely based on damage proved in general to be inadequate, as a number of industrial buildings that survived with no damage the first main shock did collapse during the second one. However, simple procedures for 


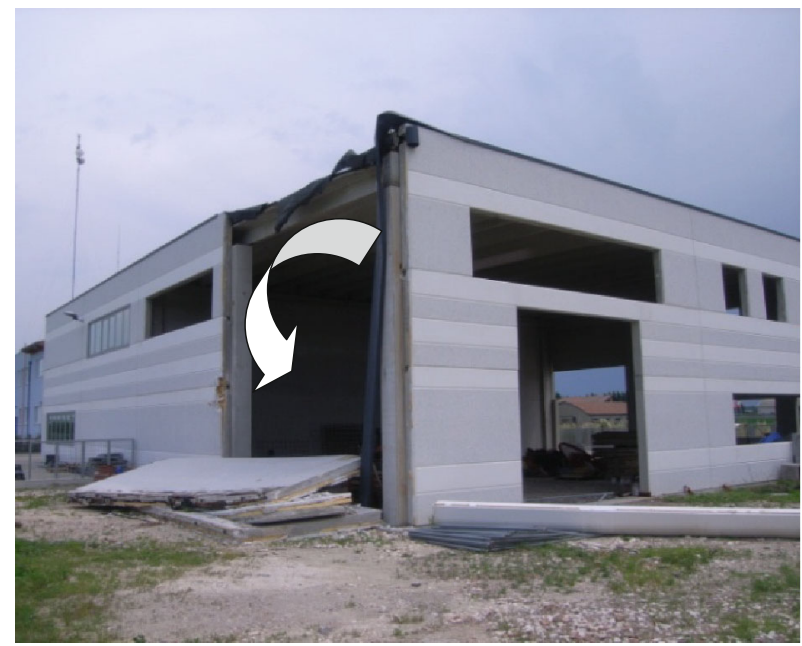

(a)

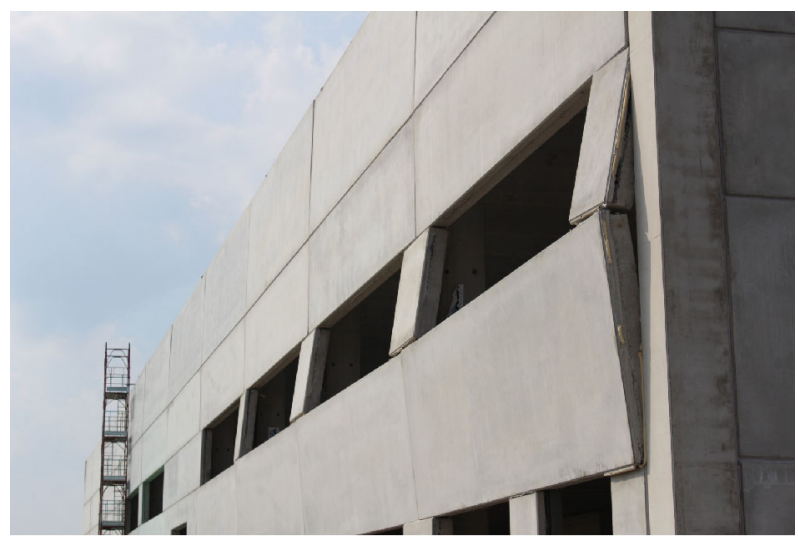

(b)

Fig. 18 Out-of-plane overturning of exterior claddings
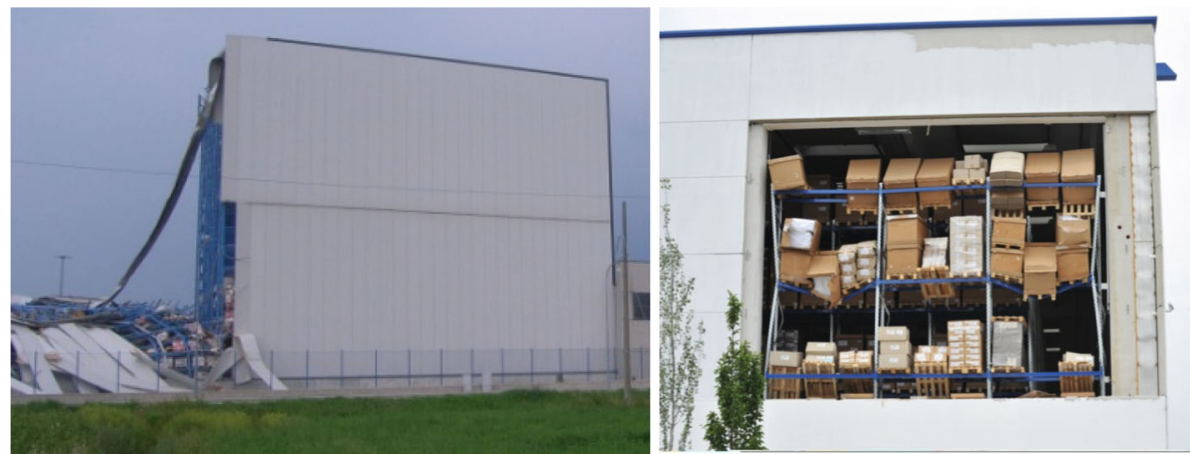

Fig. 19 Collapse and local failures attributed to the failure of rack systems 


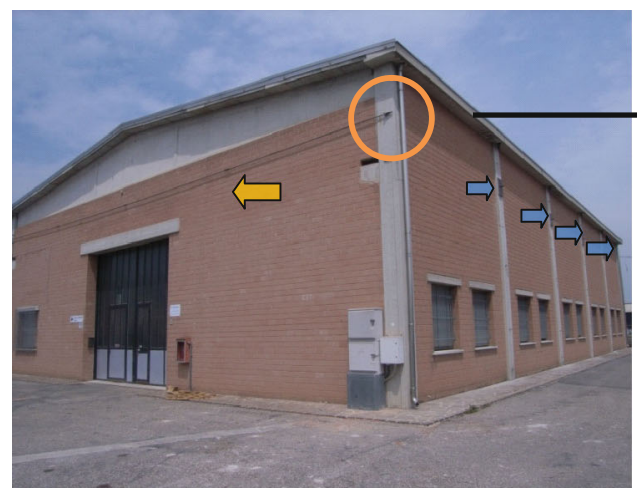

(a)

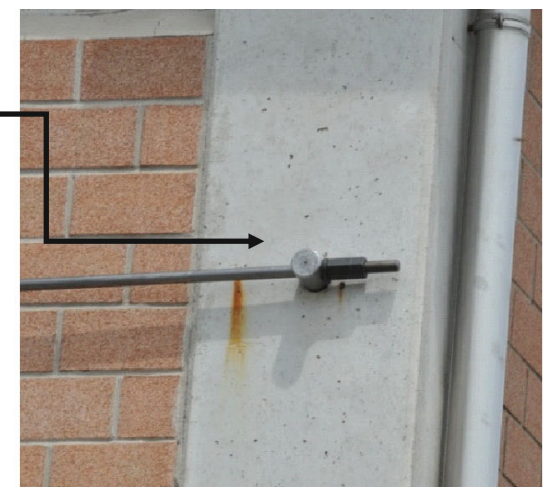

(b)

Fig. 20 a Steel ties anchorage system installed after the main event to stabilize the structure: orange arrow showing the external tie, blue arrows showing the internal ties. b Detail of the anchorage at the external tie

vulnerability assessment do not exist for this class of structures. Even if undamaged, precast buildings designed with no seismic provisions are highly vulnerable and may experience high levels of damage in the event of future aftershocks similar to the main event. Moreover, there is a high potential of indirect economical losses due to the interruption of the economic activities associated to the prefabricated industrial buildings. There is a risk of relocation of activities to areas not affected by the earthquake, which would badly impact on the economy of the affected area.

On the basis of the current situation, a series of provisional recommendations concerning the structural performance and safety of new precast buildings and the retrofit of existing ones in seismic regions are presented, regarding: (i) development of guidelines for retrofitting precast buildings designed with non-seismic provisions; (ii) development of guidelines for the rational design of connections of precast buildings in seismic regions; (iii) improvement of the design of the connections of panels; and (iv) development of guidelines for the design of steel racks in seismic regions.

\subsection{Strengthening of existing precast buildings with simply supported beams}

In response to the risk associated with the seismic response of industrial precast buildings an ordinance comprising general guidelines for vulnerability assessment and intervention was issued by the national authorities (Consiglio Superiore dei Lavori Pubblici 2012). This draft document calls for the need of adopting interventions to reduce the relative displacements between column heads and supporting beams by means of mechanically connecting the beams with the columns. At present there are not experimentally validated strengthening techniques for the seismic connection of beams simply supported to the column forks, although various retrofitting proposals for this typology of industrial buildings have been proposed.

During the field visit the team inspected a precast industrial building that had been retrofitted following the first event (after information gathered from the building owner). The building corresponded to the typology with simply supported beams on columns designed for gravity loads only. The retrofit consisted in a series of steel ties in line and below the main girders, as shown in Fig. 20. The steel ties were anchored at the top of the columns in the transverse direction and might have prevented opening of the columns and loss of seating of the girder during the 29 May event. 
Fig. 21 General concept of a retrofit solution for industrial buildings with beams simply supported on the column top comprising seismic cable restrainers and possibly additional steel reinforcement

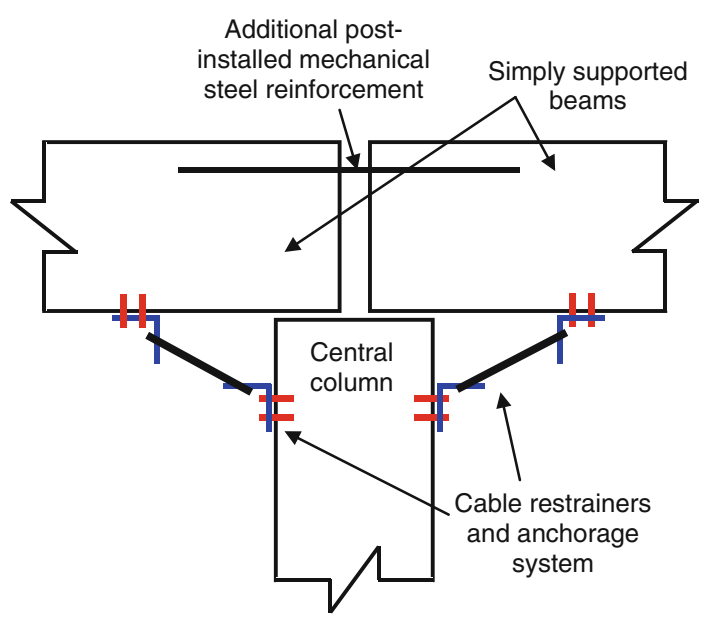

A proposal for the strengthening of existing industrial building consists in adopting a scheme which is used for the seismic retrofit of simply supported bridges: to reduce the likelihood of collapse due to unseating, cable restrainers are used between the girders and the piers/abutments of the bridge. Cable restrainers were first used in the United States after the collapse of several multi-frame bridges that collapsed due to unseating during the 1971 San Fernando earthquake in California (Jennings 1971). The performance of bridges in the 1989 Loma Prieta and 1994 Northridge earthquakes showed that cable restrainers were effective in limiting damage (Saiidi et al. 1993; Priestley et al. 1994; Moehle 1995). DesRoches et al. (2003) evaluated the force-displacement behavior of a cable restrainer assembly, used for the seismic retrofit of simply supported bridges. The cable restrainers were connected to the bridge pier using steel bent plates, angles, and undercut anchors embedded in the concrete as specified by typical bridge retrofit plans. The test results demonstrated that this strengthening configuration was effective in cases where seat widths were very small and relative displacements needed to be limited. The results of this study might form a good basis for future research on the use of cable restrainers for the retrofit of industrial buildings with beams simply supported at the top of columns (Fig. 21). The restrainers in such a system would be anchored at the column and beam ends, where the bending moment is minimum, with the advantage that their installation would not significantly disturb the functioning of the building.

\subsection{Rational seismic design of pinned beam-column connections}

The partial collapse of the industrial building with pinned beam-column connections completed in 2010 and described in Sect. 4.2.2 brought in light the lack of specific provisions for the detailing of beam-to-column connections by the Italian construction standards and the Eurocodes. To address such issues related to the seismic design of precast concrete structures a large amount of pre-normative research (e.g. Ferrara et al. 2004, 2006; Negro et al. 2007) for the development and maintenance of the Eurocodes was carried out at the European Laboratory for Structural Assessment (ELSA) of the Joint Research Centre (JRC) of the European Commission at Ispra (Italy). To this end the research project SAFECAST (Performance of innovative mechanical connections in precast buildings structures under seismic conditions, Grant agreement no 218417-2), financed by the Seventh Framework Programme 
of the European Commission, was recently undertaken to fill the gap in the knowledge of the seismic behavior of the mechanical connections used in precast concrete structures. A set of guidelines for the design of connections of precast structures in seismic areas was finally delivered in the framework of SAFECAST (Negro and Toniolo 2012).

The structural capacity of pinned beam-column connections, which represent the most common connection system in construction practice in Europe was investigated by the National Technical University of Athens (Psycharis and Mouzakis 2012) and the University of Ljubljana (Fischinger et al. 2012).

Based on the work of Psycharis and Mouzakis (2012), a rational procedure for the seismic design and proper detailing of pinned beam-to column connections was proposed. Following the concept of EC8, the connections are overdesigned with respect to the strength of beam and column. The prevailing energy dissipation mechanism of the structure relies on the formation of plastic hinges within the critical regions of the columns, with the connections remaining elastic. The design of the columns is based on a prescribed force reduction factor $q$, whereas the design of the connections follows the capacity design rule: the design shear force $E_{d}$ for the connection is obtained assuming that the ultimate flexural resistance is developed at the base of the column, calculated by multiplying its flexural resistance $M_{R d}$ by the overstrength factor $\gamma_{R d}$. Verification for the shear resistance of the connection $R_{d}$ is made, namely by satisfying the inequality $E_{d} \leq R_{d}$. On the basis of the experimental results obtained by Psycharis and Mouzakis (2012) the following formula for the shear resistance of the connection was proposed:

$$
\begin{aligned}
& R_{d}=\frac{C_{0}}{\gamma_{R d}} \times n \times D^{2} \times \sqrt{f_{c d} \times f_{y d}}, \quad \text { for } d / D>6 \\
& R_{d}=\frac{C_{0}}{\gamma_{R d}} \times(0.25 d / D-0.50) \times n \times D^{2} \times \sqrt{f_{c d} \times f_{y d}}, \quad \text { for } 4 \leq d / D \leq 6
\end{aligned}
$$

where $C_{0} \approx 0.90 \div 1.10$ is a coefficient that depends on the expected joint rotations. For large joint rotations (flexible columns) a value of around 0.90-0.95 is suggested, while for small joint rotations (stiff columns and walls) it may be increased up to the maximum value of 1.10 , for practically zero joint rotations. $f_{c k}$ and $f_{s y}$ are the characteristic strengths of concrete and steel (units in MPa), with their design values $f_{c d}=f_{c k} / \gamma_{c}$ and $f_{y d}=f_{s y} / \gamma_{s}$, where $\gamma_{c}$ and $\gamma_{s}$ are the partial safety factors for concrete and steel. The recommended values for these coefficients in Eurocodes 2 and 8 are: $\gamma_{c}=1.50$ and $\gamma_{s}=1.15 . D$ is a diameter of the dowel, $d$ the distance from the centre of the dowel to the face of the column (units in $\mathrm{mm}$ ), and $n$ is the number of dowels. The suggested general safety factor $\gamma_{R d}$ is equal to 1.30 as proposed by fib 2008 (Federation International du Beton (fib) 2008).

In addition, a series of specific provisions for the detailing of hinged beam-column joints were proposed by Psycharis and Mouzakis (2012):

- It was suggested to use a sufficient cover of the dowels $(d / \mathrm{D} \geq 6)$, otherwise spalling might occur, which much decrease their resistance.

- The presence of horizontal hooks in front of the dowels was found to be very important for the hinged joint's seismic response.

- The use of high strength grout inside the sleeves increases the resistance of the connection and improves its cyclic response by decreasing pinching and increasing ductility.

- For flexible columns, large rotations can occur at the joints, which reduces shear strength and increase damage to the connection, which increases with repeated cycles.

Besides the tests on individual beam-column joints, within the SAFECAST project a series of pseudodynamic tests on a full-scale three-storey precast concrete building, com- 


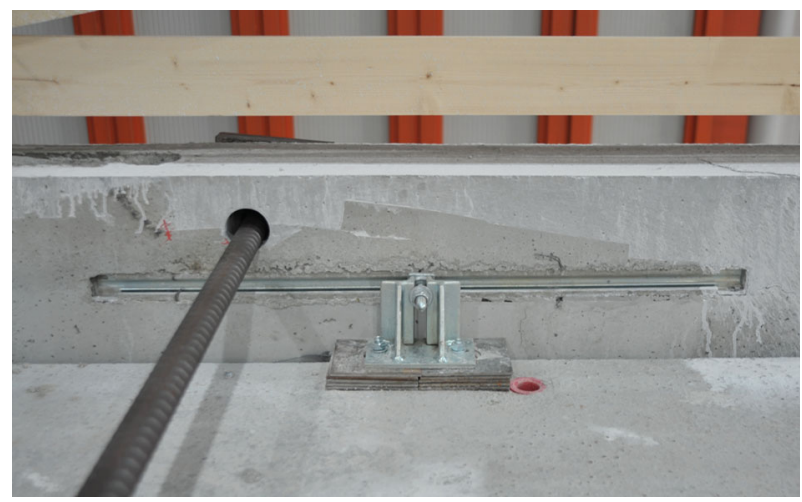

Fig. 22 Panel connection device that provides resistance in the vertical and out-of-plane directions and accommodates large relative deformations in the lateral direction

prising pinned beam-column connections, were carried out at the ELSA Laboratory. On the basis of these tests it was shown that in the case of multi-storey buildings with hinged beam-to-column connections, due to the participation of the higher modes, there is no reduction of the inter- storey forces when the structure enters into the nonlinear regime, as one would expect as a consequence of ductility. This resulted into large (i.e., much larger than when taking into account the $q$ factor) forces in the beam-column connections. Therefore, the large magnification of storey forces should be considered in determining the capacity of the pinned connections. A possible conservative simplification could be to multiply the design storey forces in all stories by $q$ (Fischinger et al. 2012; Negro et al. 2014; Bournas et al. 2014), even though less conservative approaches have also been developed (Fischinger et al. 2012).

\subsection{Design measures for claddings}

The detachment of cladding panels from the main structure due to insufficient capacity of their connections with the main structure demonstrated their high vulnerability. Classifying precast claddings as non-structural elements because they are not expected to contribute to the strength of the building is indeed misleading, since they may provide stiffness contribution at large drifts, inducing failure of their connections resulting in the fall of panels up to 10 tons of weight. The threat to humans of these collapses requires a different approach. These considerations hold true for all, precast and cast-in-situ, concrete structures.

In order to ensure the standard design approach in which the claddings do not contribute to seismic response, stringent design criteria for the design of the connections should be enforced: connections devices should be able to provide the required strength in the vertical and out-of-plane directions while accommodating large relative deformations in all other directions (Fig. 22). A viable option would be to prescribe adequate fail-safe restraints, so that the panels would not fall even in case the relative displacement capacity of the connection is exceeded.

Another possibility would be to design the claddings and their connections as being an integral part of the structure, by adequately taking into account their strength and stiffness in the design model. 


\subsection{Guidelines for the design of steel racks}

The field survey of the inspection team demonstrated that storage racks systems can indeed be very large, and the consequences of their failure can have considerable economic impacts. Since storage steel racks are not considered as 'civil structures', there are no commonly accepted design rules, with the exception of a series of guidelines developed for the seismic design of storage racks and produced as outcome of a the European project SEISRACKS (Storage Racks in Seismic Areas, Contract Number: RFS-PR-03114) (Rosin et al. 2009). Storage racks systems, especially very tall ones, should be adequately designed, with stringent acceptance requirements and adequate maintenance procedures.

The field visit revealed that the large flexibility of tall storage racks led to hammering against the main structure and the concrete claddings, which ultimately caused their failure. The provisions for the design of a racking system should exclude the possibility of attaching the steel racks to the structure or to the claddings, and adequate clearances should be provided to exclude the likelihood of hammering.

\section{Conclusions}

The present paper follows a technical mission to the area affected by the earthquake focusing mainly on the performance of precast industrial buildings. From the findings of the field reconnaissance mission, the following set of conclusions and recommendations may be drawn:

- Most of the damage experienced by precast industrial buildings in the affected area was observed in buildings designed according to the seismic zoning in force until 2003, which classified the area as non-seismic, corresponding to a design for gravity loads only, with beam-to-column joints not capable of transferring horizontal loads and isolated column foundations.

- Approximately $75 \%$ of the precast industrial buildings designed with no seismic provisions presented damage and detachment of the exterior cladding, with $25 \%$ presenting partial or total collapse of the roof and girders.

- The weak link in the majority of industrial buildings designed with no seismic provisions only was the absence of a mechanical connection between beams and columns. This resulted in a large number of collapses induced by unseating of the main beams. The loss of seating occurred mainly in the central columns, where the seating length of the girders was rather limited. In other cases the collapse of girders took place in the out of plane direction — of the girder - following failure of the lateral restrains at the top of the column.

- Industrial buildings designed under the seismic zoning in force at the time of the earthquake and corresponding to $0.15 \mathrm{~g}$ PGA (475 year return period) exhibited better seismic performance. However, the partial collapse of a building with pinned beam-column connections completed in 2010 and designed following the Italian construction standards brought in light the lack of specific provisions for the detailing of beam-to-column connections.

- The detachment of cladding panels from the main structure was practically not improved in the newly constructed buildings, due to insufficient capacity of the connections between the panels and the structure to accommodate in-plane displacements and resist the outof-plane inertial forces of the panels. 
- It is recommended to develop guidelines for the seismic retrofit of precast buildings designed with non-seismic provisions, in particular for the beam-to-column connections and for the connections of the cladding panels with the structure. Such guidelines will be of very much use in similar areas in Europe that are upgrading their seismic zoning, classifying as seismic areas that have been historically considered as non-seismic.

- The development of guidelines for new precast buildings in seismic regions for the prescriptive design and detailing of beam-to-column connections and for the connections of cladding panels to the structure is an urgent need. The design methods and procedures proposed by the SAFECAST Project constitute a step forward in this direction.

- Failure of steel racking systems was observed in several industrial buildings, leading in many cases to the subsequent collapse of the exterior cladding. It is recommended that guidelines for the design of steel racking systems in seismic regions are developed in order to prevent such type of failures.

Acknowledgments The authors received much useful information from the colleagues of the CRITECH and GEMMA actions of the Global Security and Crisis Management Unit of the Institute for the Protection and Security of the Citizen of the Joint Research Centre, in providing the first situation reports of the affected area as well as preliminary aerial and satellite images of the damaged buildings. The authors wish to thank Dr. A. Colombo for her support during the field mission.

Open Access This article is distributed under the terms of the Creative Commons Attribution License which permits any use, distribution, and reproduction in any medium, provided the original author(s) and the source are credited.

\section{References}

Bonacina G, Indirli M, Negro P (1994) The January 17, 1994 Northridge Earthquake-report to the sponsor: earthquake engineering field investigation team, Special publication no. I.94.14, 1994, Ispra (VA), Italy

Bournas D, Negro P, Molina FJ (2014) Pseudodynamic tests on a full-scale 3-storey precast concrete building: behavior of the mechanical connections and floor diaphragms. Elsevier Eng Struct J 58

Consiglio Superiore dei Lavori Pubblici (2012) Valutazione della vulnerabilità e onterventi per le costruzioni ad uso produttivo in zona sismica. http://www.mit.gov.it/mit/mop_all.php?p_id=12505

Chioccarelli E, Iervolino I (2010) Near-source seismic demand and pulse-like records: a discussion for L'Aquila earthquake. Earthq Eng Struct Dyn 39:1039-1062

CEN (2004) European standard EN 1998-1: Eurocode 8: design of structures for earthquake resistance-part 1: general rules, seismic actions and rules for buildings. European Committee for Standardization, Brussels

DesRoches R, Thomas P, Leon RT, Lam T (2003) Full-scale tests of seismic cable restrainer retrofits for simply supported bridges restrainer design methods for simply supported bridges. ASCE J Bridge Eng 6(5):307-315

EERI, Stratta J, Loring W (1979) Friuli, Italy earthquakes of 1976, Earthquake Engineering Research Institute

EERI (1989) Armenia earthquake reconnaissance report, Earthquake spectra supplement

EERI (2000) Kocaeli, Turkey, Earthquake of August 17, 1999, Earthquake spectra supplement

Fajfar P, Duhovnik J, Reflak J, Fishinger M, Breska Z (1981) The behaviour of Buildings and other structures during the earthquake of 1979 in Montenegro. University of Ljubljana, IKPIR Publication no 19A

Ferrara L, Colombo A, Negro P, Toniolo G (2004) Precast vs. cast-in-situ reinforced concrete industrial buildings under earthquake loading: an assessment via pseudodynamic tests. In: Proceedings of the 13 th WCEE

Ferrara L, Mola E, Negro P (2006) Pseudodynamic and cyclic testing of full scale prototypes of precast $\mathrm{R} / \mathrm{C}$ one storey buildings. In: Proceedings of the 1 st European conference on earthquake engineering and seismology, Geneva, September 3-8

Fischinger M, Isaković T, Kramar M (2012) Experimental behaviour of existing connections-part two: contribution of the University of Ljubljana. SAFECAST-Deliverable 2.1. Grant agreement no. 218417-2, $68 \mathrm{p}$

Federation International du Beton (fib) (2008) Structural connections for precast concrete buildings. Bulletin $43: 370$ 
Iervolino I, De Luca F, Chioccarelli E (2012) Engineering seismic demand in the 2012 Emilia sequence: preliminary analysis and model compatibility assessment. Ann Geophys 55:4

Jennings PC (1971) Engineering features of the San Fernando earthquake of February 9, 1971. Rep. No. EERL-76/18, Earthquake Engineering. Research Laboratory, California Institute of Technology, Pasadena, Calif

Monitoring and Information Centre (MIC) (2009) Community civil protection mechanism. Technical report Italy Earthquake, http://ec.europa.eu/echo/files/aid/countries/italy_report1.pdf

Moehle JP (1995) Northridge earthquake of January 17, 1994: reconnaissance report. Volume 1: highway bridges and traffic management. Earthquake Spectra 11(Suppl.):287-372

Negro P, Mola E, Ferrara L, Zhao B, Magonette G, Molina J (2007) Precast structures EC8: seismic behaviour of precast concrete structures with respect to EC8-contract. G6RD-CT-2002-00857. Final report of the experimental activity of the Italo-Slovenian Group, $190 \mathrm{p}$

Negro P, Bournas D, Molina FJ (2014) Pseudodynamic tests on a full-scale 3-storey precast concrete building: global response. Elsevier Eng Struct J 58

Negro P, Toniolo G (2012) Design guidelines for connections of precast structures under seismic actions. Report EUR 25377 EN, European Commission. http://elsa.jrc.ec.europa.eu/publications/LBNA25377ENN.pdf

Olgiati M, Negro P, Bournas D (2011) Literature survey and identification of needs-part two: general survey and design procedures. Contribution of the Joint Research Centre. SAFECAST-Deliverable 1.2. Grant agreement no. 218417-2, $190 \mathrm{p}$

USGS Pager System-prompt assessment of global earthquakes for response. http://earthquake.usgs.gov/ earthquakes/pager/

Priestley MJN, Seible F, Uang CM (1994) The Northridge earthquake of January 17, 1994: damage analysis of selected freeway bridges. Rep. no. SSRP-94/06, Department of Applied Mechanics and Engineering Sciences, University of California, San Diego

Psycharis I, Mouzakis H (2012) Shear resistance of pinned connections of precast members to monotonic and cyclic loading. Elsevier Eng Struct 41:413-427

Rosin I, Calado L, Proenca J, Carydis P, Mouzakis H, Castiglioni C, Brescianini JC, Plumier A, Degee H, Negro P, Molina FJ (2009) Storage racks in seismic areas. Report EUR 23744 EN, European Commission

Saatcioglu M, Mitchell D, Tinawi R, Gardner NJ, Gillies AG, Ghobarah A, Anderson DL, Lau D (2001) The August 17, 1999 Kocaeli (Turkey) earthquake-damage to structures. Can J Civil Eng 28(8):715-773

Saiidi M et al (1993) Response of bridge hinge restrainers during earthquakes: field performance, analysis, and design. Rep. no. CCEER93-6, Center for Civil Engineering Earthquake Research, University of Nevada, Reno, Nev

Toniolo G, Colombo A (2012) Precast concrete structures: the lessons learned from the L'Aquila earthquake. Struct Concr 13:73-83

Tzenov LL, Sotirov, Boncheva P (1978) Study of some damaged industrial buildings due to Vrancea earthquake. In: Proceedings of 6th ECEE Dubrovnik, vol 6, pp 59-65

Wood SL (2006) Seismic rehabilitation of low-rise precast industrial buildings in Turkey. Springer advances in earthquake engineering for urban risk reduction (NATO science series: IV: earth and environmental sciences), vol 66, pp 167-177 